\begin{tabular}{c|c|c}
\hline \hline Vol. 270: 153-161, 2004 & MARINE ECOLOGY PROGRESS SERIES \\
Mar Ecol Prog Ser & Published April 14 \\
\hline
\end{tabular}

\title{
Imposex in Nucella lapillus: a ten year survey in NW Brittany
}

\author{
M. Huet*, Y. M. Paulet, J. Clavier \\ LEMAR, UMR CNRS 6539, Institut Universitaire Européen de la Mer, Université de Bretagne Occidentale, \\ Place Copernic, 29280 Plouzané, France
}

\begin{abstract}
Tributyltin (TBT) pollution has been assessed in NW Brittany since 1992 using the bioindicator imposex in Nucella lapillus. The Bay of Brest is highly polluted by TBT and the outgoing water mass has contaminated the adjacent NW coasts. However environmental conditions have been improving in NW Brittany. The decrease in TBT pollution is most likely due to the reformulated antifouling paints (with slower leaching rates or TBT-free) that are used for civil and military careening activities in the Bay of Brest. An increase in imposex levels in 1998 could have been due to the launching of the aircraft carrier 'Charles de Gaulle'. It remains unknown when imposex levels reached their maximum because of the lack of annual surveys in 1996, 1997 and 1999. This underscores the need for annual surveys when using imposex as a monitoring tool. At 3 locations within the Bay of Brest, new populations of $N$. lapillus have appeared since 1998. At other stations, populations have grown in number of individuals and colonised adjacent rocks. The percentage of less severely affected imposex females (vas deferens sequence stage 3) has increased since 1998. As TBT could soon be banned from antifouling paints, further recovery of favourable environmental conditions for N. lapillus is expected.
\end{abstract}

KEY WORDS: Nucella lapillus $\cdot$ Pollution · Tributyltin $\cdot$ Imposex $\cdot$ Brittany $\cdot$ Bioindicator

Resale or republication not permitted without written consent of the publisher

\section{INTRODUCTION}

Tributyltin (TBT) is one of the most effective toxins in marine ecosystems. It is found in TBT-based antifouling paints, the use of which became widespread during the 1970s. Large-scale deleterious effects were first described in France (Bay of Arcachon) on oysters (His \& Robert 1980, Alzieu et al. 1981). This pesticide has various negative effects on different biological functions (see Huet 1996 for review) and gastropods are among the most sensitive organisms to TBT in marine ecosystems; they suffer imposex at very low levels of contamination. The imposex condition describes a superimposition of male sexual characters onto marine gastropod females and it concerns at least 118 species worldwide (Bettin et al. 1996). Under heavily contaminated conditions, females may become sterile and subsequently, population collapse could occur (Bryan et al. 1986).

The degree of masculinisation of the female dogwhelk Nucella lapillus is known to be related to the level of TBT pollution as a dose-effect process (Bryan et al. 1986, Bailey \& Davies 1989, Oehlmann et al. 1992). It is possible, therefore, to estimate the degree of TBT pollution suffered by the ecosystem through imposex measurements (Gibbs et al. 1987). In 1992, a 10 yr-long study was begun, that was designed to assess the level of imposex in the N. lapillus populations of NW Brittany. The study was designed to monitor an expected improvement in water quality (with regard to TBT), as a consequence of the 1982 French law regulating the use of TBT-based paints. In the present paper, we examine the results of this survey.

\section{MATERIALS AND METHODS}

The study was carried out on the NW coast of Brittany (Fig. 1), with 56 stations (see Table 1) being repeatedly sampled in 1992 (February through June), 1993 (March through June), 1994 (April through May), 


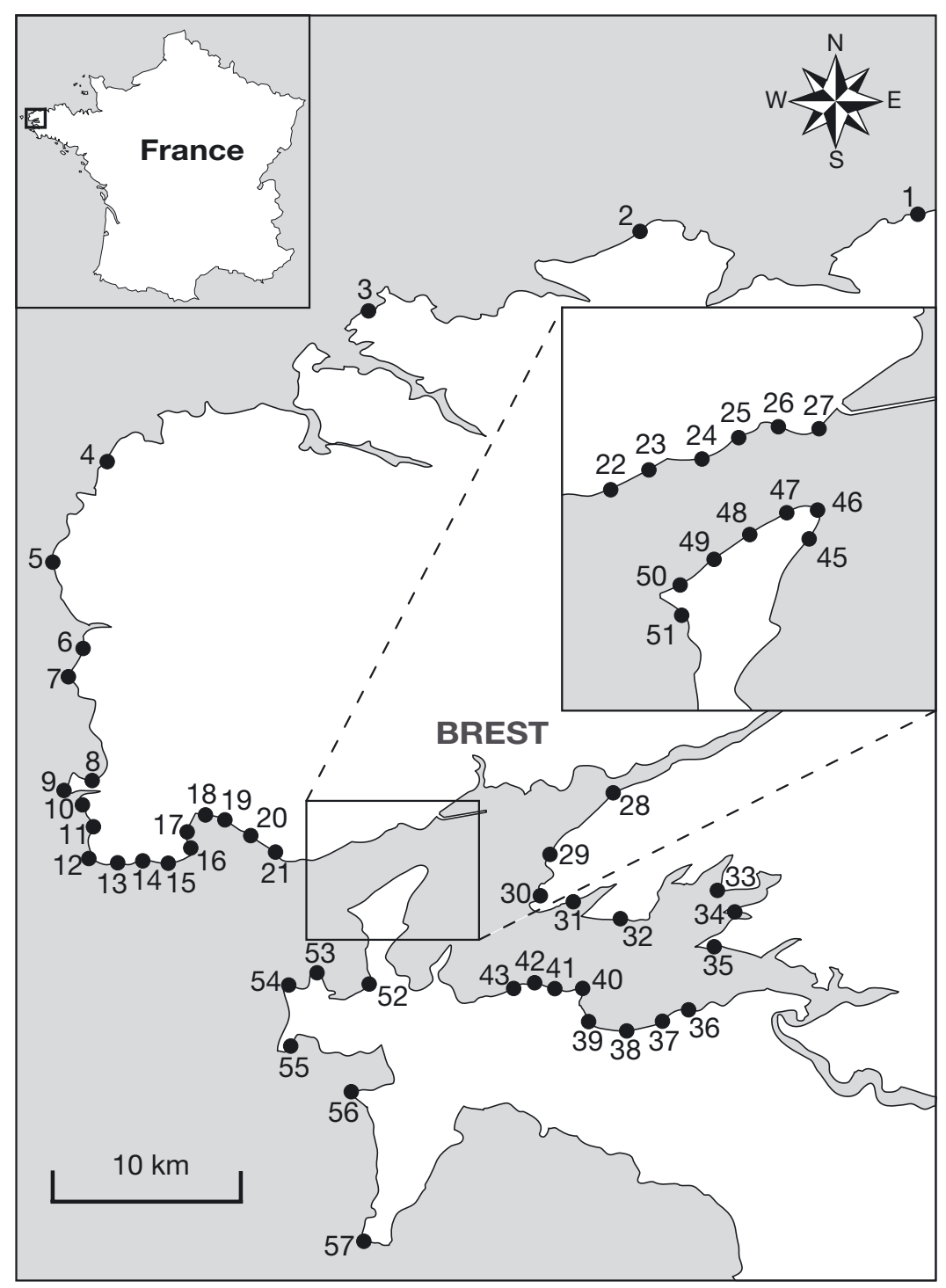

Fig. 1. Map of NW Brittany showing positions of sampling stations

1995 (March through April), 1998 (February through May), 2000 (May through September) and 2002 (February through April). At each sampling, 40 adult Nucella lapillus were collected, except in 2002 when 50 specimens were collected.

Specimens were analysed according to Huet et al. (1996a), and all samples were analysed less than $3 \mathrm{~d}$ after sampling. Shells were crushed in a vice and the soft tissues were separated from the shell remains. Sex was determined for each individual according to Fretter \& Graham (1976), Gibbs et al. (1987) and Fioroni et al. (1991). Females were recognised mainly by the presence of the large capsule gland, the dark sperm-ingesting gland, the albumen gland and the granular aspect of the ovary. The obvious characteristics of males were the yellow and smooth aspect of the testis and the presence of the white vesicula seminalis between the digestive gland and the testis. Penis length was measured to the nearest $0.1 \mathrm{~mm}$ under a binocular microscope equipped with an ocular micrometer. The relative penis size index (RPSI) was calculated as defined by Bryan et al. (1986):

$$
\text { RPSI }=\frac{(\text { mean female penis length })^{3}}{(\text { mean male penis length })^{3}} \times 100
$$

The vas deferens sequence (VDS) stages of females were assigned according to the scales of Gibbs et al. (1987) and Oehlmann et al. (1991). The area between 
Table 1. Nucella lapillus. Relative penis size (RPSI) and vas deferens sequence (VDSI) indices at 56 stations in NW Brittany. in: area of increasing imposex condition for 1998 (see Fig. 2); out: outside of area 'in' (omitting Stns 28 and 29); blank: not visited -: no N. lapillus found

\begin{tabular}{|c|c|c|c|c|c|c|c|c|c|c|c|c|c|c|c|}
\hline \multirow{2}{*}{ Stn } & \multirow{2}{*}{ Area } & \multicolumn{7}{|c|}{ - RPSI - } & \multirow[b]{2}{*}{1992} & \multirow[b]{2}{*}{1993} & \multirow[b]{2}{*}{1994} & \multirow{2}{*}{$\begin{array}{l}\text { VDSI } \\
1995\end{array}$} & \multirow[b]{2}{*}{1998} & \multirow[b]{2}{*}{2000} & \multirow[b]{2}{*}{2002} \\
\hline & & 1992 & 1993 & 1994 & 1995 & 1998 & 2000 & 2002 & & & & & & & \\
\hline 1 & out & 2 & 3 & 3 & 2 & 0 & 0 & 0 & 2.63 & 2.31 & 2.24 & 2.65 & 1.00 & 0.90 & 0.71 \\
\hline 2 & out & 5 & 14 & 10 & 12 & 6 & 11 & 2 & 3.50 & 4.00 & 3.57 & 4.00 & 3.60 & 3.00 & 2.86 \\
\hline 3 & out & 6 & 5 & 9 & 6 & 5 & 6 & 3 & 3.75 & 3.86 & 4.00 & 3.87 & 3.50 & 3.56 & 2.79 \\
\hline 4 & out & 5 & 7 & 7 & 5 & 9 & 5 & 8 & 3.95 & 4.00 & 4.00 & 3.90 & 3.74 & 3.76 & 3.94 \\
\hline 5 & out & 22 & 18 & 25 & 21 & 22 & 13 & 9 & 4.07 & 4.15 & 4.00 & 4.07 & 4.11 & 4.07 & 4.00 \\
\hline 6 & out & 22 & 18 & 23 & 17 & 19 & 20 & 16 & 4.00 & 4.00 & 4.00 & 4.44 & 4.07 & 4.00 & 4.00 \\
\hline 7 & out & 30 & 25 & 29 & 22 & 16 & 12 & 13 & 4.24 & 4.24 & 4.00 & 4.00 & 4.00 & 4.06 & 4.08 \\
\hline 8 & in & 36 & 42 & 38 & 30 & 29 & 33 & 19 & 4.15 & 4.24 & 4.07 & 4.05 & 4.13 & 4.12 & 4.00 \\
\hline 9 & in & 26 & 28 & 22 & 24 & 33 & 27 & 16 & 4.20 & 4.27 & 4.00 & 4.00 & 4.32 & 4.20 & 4.00 \\
\hline 10 & in & 16 & 29 & 23 & 18 & 23 & 22 & 26 & 4.15 & 4.16 & 4.00 & 4.27 & 4.21 & 3.93 & 4.04 \\
\hline 11 & in & 32 & 31 & 30 & 26 & 25 & 25 & 25 & 4.17 & 4.26 & 4.17 & 4.06 & 4.19 & 4.00 & 4.00 \\
\hline 12 & in & 39 & 41 & 43 & 34 & 30 & 25 & 35 & 4.09 & 4.19 & 4.21 & 4.10 & 4.05 & 4.00 & 3.96 \\
\hline 13 & in & 43 & 21 & 28 & 34 & 25 & 31 & 30 & 4.15 & 4.13 & 4.13 & 4.00 & 4.00 & 4.17 & 4.04 \\
\hline 14 & in & 64 & 54 & 32 & 40 & 35 & 29 & 33 & 4.50 & 4.29 & 4.07 & 4.21 & 4.11 & 4.00 & 4.00 \\
\hline 15 & in & 30 & 40 & 30 & 19 & 20 & 22 & 28 & 4.22 & 4.13 & 4.00 & 3.90 & 4.00 & 3.85 & 3.83 \\
\hline 16 & in & 43 & 57 & 35 & 29 & 36 & 26 & 40 & 4.40 & 4.31 & 4.20 & 4.29 & 4.22 & 4.18 & 4.00 \\
\hline 17 & in & 50 & 29 & 30 & 27 & 35 & 21 & 25 & 4.78 & 4.36 & 4.40 & 4.00 & 4.29 & 4.09 & 4.00 \\
\hline 18 & in & 36 & 23 & & 21 & 17 & 17 & 21 & 4.41 & 4.12 & 4.17 & 4.19 & 4.17 & 4.00 & \\
\hline 19 & in & 29 & 33 & 35 & 24 & 34 & 31 & 34 & 4.13 & 4.13 & 4.25 & 4.05 & 4.22 & 3.94 & 3.95 \\
\hline 20 & in & 16 & 15 & 33 & 24 & 24 & 20 & 27 & 4.29 & 4.00 & 4.00 & 4.00 & 4.20 & 4.00 & 4.05 \\
\hline 21 & in & 38 & 60 & 47 & 36 & 48 & 21 & 39 & 4.27 & 4.33 & 4.07 & 4.00 & 4.18 & 4.13 & 4.22 \\
\hline 22 & in & 37 & 40 & 30 & 44 & 50 & 52 & 35 & 4.20 & 4.16 & 4.36 & 4.31 & 4.00 & 4.07 & 4.00 \\
\hline 23 & in & 17 & 33 & 26 & 23 & 19 & 20 & 22 & 4.29 & 4.35 & 4.29 & 4.17 & 4.29 & 4.00 & 4.21 \\
\hline 24 & in & 37 & 41 & 27 & 23 & 18 & 26 & 26 & 4.00 & 4.35 & 4.31 & 4.20 & 4.15 & 3.90 & 4.00 \\
\hline 25 & in & 62 & 57 & 34 & 42 & 43 & 44 & 33 & 4.54 & 4.77 & 4.38 & 4.26 & 4.54 & 4.17 & 4.17 \\
\hline 26 & in & 41 & 45 & 28 & 42 & 43 & 30 & 34 & 4.61 & 4.31 & 4.25 & 4.00 & 4.28 & 4.15 & 4.17 \\
\hline 27 & in & 47 & 50 & 32 & 29 & 35 & 34 & 34 & 4.00 & 4.20 & 4.31 & 4.00 & 4.25 & 4.10 & 4.14 \\
\hline 28 & in & 75 & - & - & 78 & 74 & 80 & 76 & 6.00 & - & - & 5.24 & 5.24 & 5.00 & 5.22 \\
\hline 29 & in & 66 & & - & - & 52 & 25 & 28 & 5.00 & & - & - & 4.29 & 4.57 & 4.18 \\
\hline 30 & in & 49 & 49 & 33 & 43 & 39 & 20 & 28 & 4.36 & 4.60 & 4.62 & 4.20 & 4.24 & 4.14 & 4.07 \\
\hline 31 & in & 39 & 43 & 34 & 18 & 26 & 25 & 23 & 4.56 & 4.24 & 4.25 & 4.13 & 4.17 & 4.18 & 4.15 \\
\hline 32 & out & 38 & 45 & & 28 & 23 & 23 & 31 & 4.62 & 4.60 & 4.62 & 4.29 & 4.11 & 4.15 & \\
\hline 33 & out & 20 & 19 & 30 & 16 & 19 & 25 & 23 & 4.27 & 4.00 & 4.00 & 4.22 & 4.09 & 4.14 & 4.06 \\
\hline 34 & out & 21 & 35 & & 25 & 24 & 26 & 28 & 4.45 & 4.12 & 4.08 & 4.00 & 4.06 & 4.00 & \\
\hline 35 & out & 46 & 42 & & 29 & 32 & 43 & 40 & 4.43 & 4.17 & & 4.08 & 4.13 & 4.17 & 4.17 \\
\hline 36 & out & 32 & 25 & 37 & 36 & 26 & 36 & 27 & 4.72 & 4.30 & 4.22 & 4.17 & 4.36 & 4.26 & 4.04 \\
\hline 37 & out & 43 & 22 & & 33 & 26 & 15 & 24 & 4.68 & 4.31 & & 4.25 & 4.00 & 4.00 & 4.05 \\
\hline 38 & in & 40 & 54 & 20 & 29 & 36 & 30 & 39 & 4.50 & 4.31 & 4.00 & 4.18 & 4.35 & 4.06 & 4.11 \\
\hline 39 & in & 41 & & & - & 15 & 16 & 32 & 5.25 & & & - & 4.00 & 4.00 & 4.00 \\
\hline 40 & in & 37 & 38 & 23 & 29 & 17 & 16 & 18 & 4.75 & 4.32 & 4.06 & 4.25 & 4.06 & 4.00 & 3.94 \\
\hline 41 & in & 45 & 54 & 22 & 19 & 29 & 42 & 12 & 4.77 & 4.27 & 4.15 & 4.05 & 4.06 & 4.18 & 3.88 \\
\hline 42 & in & 32 & 47 & 31 & 26 & 36 & 35 & 30 & 4.12 & 4.33 & 4.17 & 4.07 & 4.23 & 4.21 & 4.21 \\
\hline 43 & in & 32 & 43 & 28 & 33 & 43 & 35 & 38 & 4.47 & 4.33 & 4.15 & 4.00 & 4.21 & 4.25 & 4.06 \\
\hline 45 & in & 39 & 32 & 41 & 23 & 27 & 11 & 45 & 4.64 & 4.27 & 4.23 & 4.00 & 4.47 & 4.30 & 4.23 \\
\hline 46 & in & 23 & 24 & 20 & 21 & 43 & 19 & 32 & 4.18 & 4.09 & 4.08 & 4.08 & 4.20 & 4.00 & 4.31 \\
\hline 47 & in & 33 & 19 & 36 & 27 & 16 & 15 & 18 & 4.28 & 4.00 & 4.25 & 4.13 & 4.08 & 4.13 & 3.94 \\
\hline 48 & in & 19 & 31 & 22 & 21 & 17 & 12 & 14 & 4.22 & 4.40 & 4.30 & 4.27 & 4.19 & 4.21 & 4.07 \\
\hline 49 & in & 30 & 31 & 28 & 27 & 42 & & 27 & 4.55 & 4.29 & 4.13 & 4.22 & 4.09 & & 4.07 \\
\hline 50 & in & 31 & 35 & 39 & 20 & 31 & 31 & 31 & 4.33 & 4.13 & 4.00 & 4.00 & 4.17 & 4.00 & 4.00 \\
\hline 51 & in & 22 & 35 & 32 & 14 & 48 & 31 & 18 & 4.33 & 4.27 & 4.13 & 4.00 & 4.17 & 4.23 & 4.00 \\
\hline 52 & out & 52 & 28 & 31 & 29 & 25 & 28 & 22 & 4.18 & 4.00 & 4.00 & 4.20 & 4.15 & 4.18 & 4.09 \\
\hline 53 & out & 19 & 12 & 16 & 14 & 23 & 12 & 14 & 4.19 & 4.08 & 4.07 & 4.12 & 3.91 & 3.86 & 3.96 \\
\hline 54 & out & 27 & 23 & 25 & 18 & 11 & 15 & 15 & 4.22 & 4.06 & 4.13 & 4.07 & 3.95 & 4.13 & 3.88 \\
\hline 55 & out & 13 & 13 & 13 & 10 & 8 & 8 & 11 & 4.06 & 4.00 & 4.17 & 4.00 & 4.00 & 4.00 & 4.00 \\
\hline 56 & out & 9 & 11 & 13 & 12 & 7 & 8 & 8 & 3.93 & 4.00 & 4.00 & 4.00 & 3.92 & 4.00 & 3.95 \\
\hline 57 & out & 9 & 12 & 19 & 11 & 8 & 9 & 8 & 3.95 & 4.00 & 4.00 & 4.00 & 3.90 & 4.00 & 3.95 \\
\hline
\end{tabular}




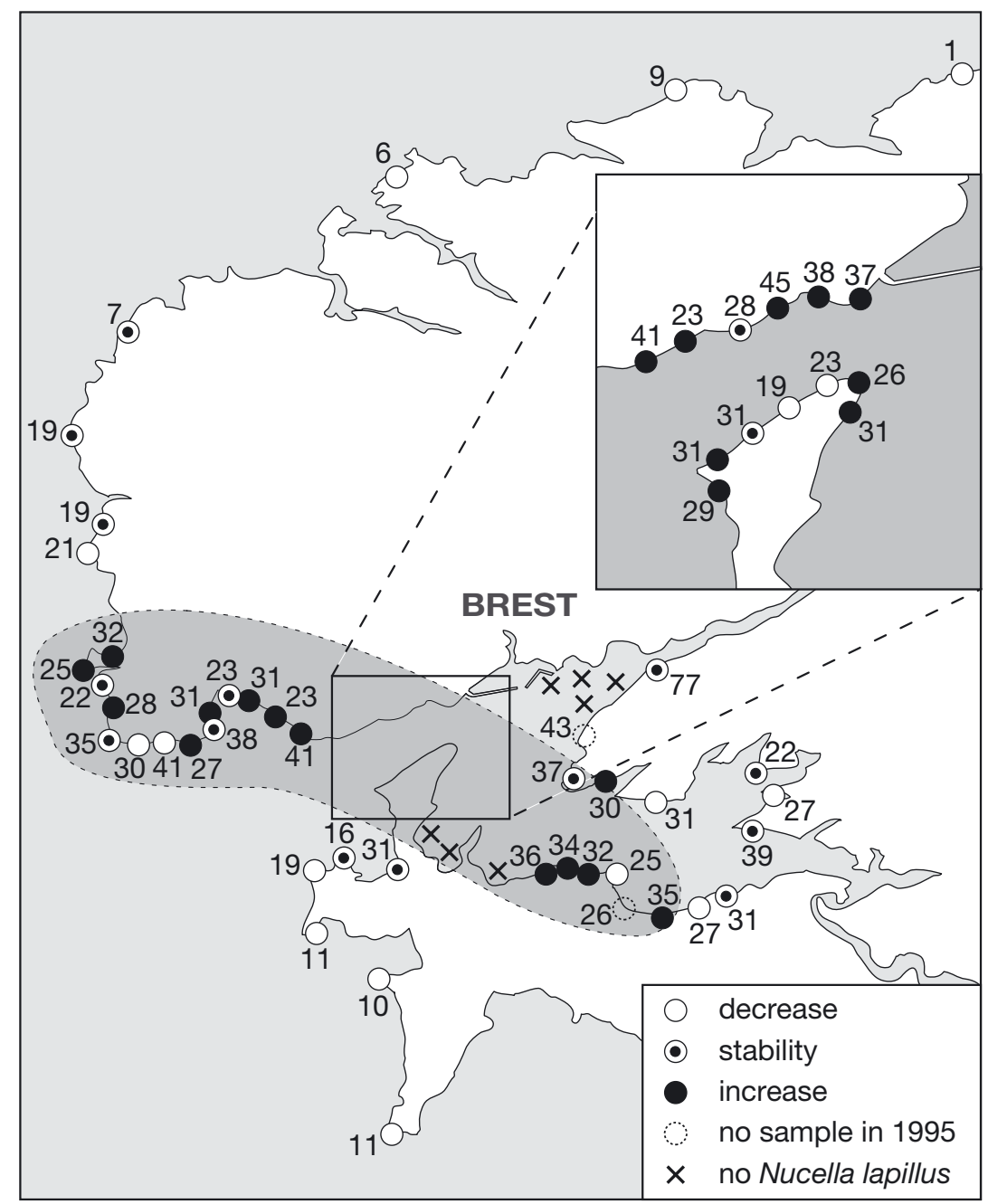

Fig. 2. Nucella lapillus. Distribution of mean relative penis size (RPS) values (1992-2002 surveys, index value next to each symbol) in NW Brittany comparing imposex indices calculated for 1995 and 1998 surveys. Shaded area: area of increasing imposex incidence in 1998

the head and the genital papilla was observed after cutting the dorsal mantle foil longitudinally. The VDS index (VDSI) was calculated as the mean of the VDS stages.

As previously described in Huet et al. (1996b), some abnormal individuals, with atypical penis development, were observed in NW Brittany. This malformation is called 'Dumpton syndrome' (DS) (Gibbs 1993). DS-affected males, lacking or with a very short penis, were omitted from calculation of the RPSI to avoid overestimation of the index. DSaffected females were also discarded from the calculation of both RPSI and VDSI, as they do not develop a penis and exhibit less imposex development than non DS-affected females. Had they been included in the calculation, then both indices would have been underestimated.
When individuals were suspected of sex-change or DS, they were kept for histological study. The genital systems of these individuals were embedded in paraplast. Serial sections, $7 \mu \mathrm{m}$ thick, were cut from the paraplast preparations and stained before observation. Comparisons between successive surveys were done using a non-parametric procedure (signed-rank test) on paired samples.

\section{RESULTS}

\section{Imposex in NW Brittany}

RPS and VDS indices are presented in Table 1. No population was free of imposex (Fig. 2). The lowest indices were observed in the north, at Kerfissien (Stn 1, Fig. 1). Since 1992, an increasing gradient of RPSI val- 
ues has been observed from Saint-Samson (Stn 4) down to Pointe Saint-Mathieu (Stn 12). In the southern part of the study area (Stns 53 to 57 ), values were low with no female sterility observed. Between the 2 areas (Stns 13 to 52, corresponding to the Bay of Brest and immediate surroundings), female sterility was common (mean 9\%) and RPSI values ranged from 11 to 80 (mean 32). The highest TBT contamination level was measured at Stn 28, in the northern part of the bay. Of particular interest were the 2002 histological observations for Stn 28, which revealed the presence of spermiogenesis in the gonad of 4 sex-changed females out of the 27 females in the sample.

\section{Temporal evolution}

The mean VDSI decreased significantly from survey to survey, except in 1998 when the decrease was not significant (Tables 1 \& 2). The mean RPSI also exhibited a decreasing trend from 1992 onwards; the increase in 1998 was not significant. In 1998 there was a temporary increase in both indices that was limited to 22 stations inside the Bay of Brest and on the adjacent north coast (Fig. 2: shaded area). If all 35 stations inside the area of increasing imposex condition for 1998 are pooled, then the mean RPSI and mean VDSI increased significantly in 1998 (Table 2, Fig. 3). The temporal evolution of VDS stage distributions at these locations is presented in Fig. 4. VDS stages 0, 1 and 2 are not shown because they were never assigned to more than $0.3 \%$ of the females. Stage 4 was predominant (71 to $90 \%$ ). In 1998, a significant increase in the percentage of sterilisation (Stages 5, 6 and 7) with a simultaneous significant decrease of the occurrence of Stage 4 was observed. The percentage of sterilisation decreased from 1992 to 2002, except in 1998. Thus the occurrence of Stage 4 increased until at least 1995. In 2002, the occurrence of Stage 3 increased markedly, with a correlative decrease in Stage 4 ; this highlights the fact that Stages 5, 6 and 7 have progressively been replaced by Stage 4, which is now being progressively replaced by Stage 3. When Stns 28 and 29 were discarded, then stations outside the area of increasing imposex in 1998 showed a continuous decrease in both imposex indices (Table 2, Fig. 3).

At 2 locations where extinction of Nucella lapillus was observed in 1995 (Stns 29 and 39), new populations were discovered in 1998. In 2002, a new population was discovered between Stns 26 and 27 where no individuals had been observed during an intensive survey in 1992. In other places in the Bay of Brest (Stns $31,32,35$ and 37 ) where only a few individuals were observed in the early 1990s, populations are now flourishing and have spread to adjacent rocks.

\section{DISCUSSION}

\section{Temporal evolution}

In NW Brittany, imposex levels in Nucella lapillus have decreased since the first observations in 1992, as well as the TBT concentrations in the seawater since 1989 (Michel \& Averty 1997, 1999). In 1992, Michel \& Averty (1997) found TBT concentrations of 0.5 to $48.8 \mathrm{ng} \mathrm{l}^{-1}$ in the waters of the Brest area. They compared their results with the data obtained in 1989 and 1990 and found that TBT pollution had decreased. In 1997, Michel \& Averty (1999) measured a maximal value of $37.4 \mathrm{ng} \mathrm{l}^{-1}$ in Brest Harbour, and described a general decrease in TBT concentrations in French seawaters compared to 1992 conditions. Similar improvements of imposex condition have been reported in other areas where legislative bans of TBT were effective, such as in the North Sea (Evans et al. 1991, 1996, Harding et al. 1997, Birchenough et al. 2002a), SW England (Bryan et al. 1993), Ireland (Minchin et al. 1995), Australia (Rees et al. 2001) and Canada (Reitsema et al. 2002). Despite the same legislative ban of TBT, a reverse trend has been observed in Spain (Ruiz et al. 1998, Ramon \& Amor 2001) and in Portugal (Barroso \& Moreira 2002, Santos et al. 2002). In Thailand, where no restriction of TBT use has been introduced, imposex has increased (Bech 2002)

In France, a partial ban of TBT in antifouling paints was imposed in 1982 for boats less than $25 \mathrm{~m}$ long. Our results show that, in the second decade after these restrictive measures were put in place (1992-2002), imposex continues to decrease in the

Table 2. Nucella lapillus. Statistical differences in relative penis size (RPS) and vas deferens sequence (VDS) indices between successive surveys. Area in: area of increasing imposex condition for 1998 (see Fig. 2); Area out: outside of area 'in' (omitting Stns 28 and 29). NS: not significant S: significant at $\mathrm{p}<0.05$

\begin{tabular}{|ccccc|}
\hline Index & $\begin{array}{c}\text { Survey years } \\
\text { compared }\end{array}$ & $\begin{array}{c}\text { All 56 } \\
\text { stations }\end{array}$ & Area in & Area out \\
\hline RPS & 1992,1993 & NS & NS & NS \\
& 1993,1994 & S & S & NS \\
& 1994,1995 & S & NS & S \\
& 1995,1998 & NS & S & NS \\
& 1998,2000 & NS & S & NS \\
& 2000,2002 & NS & NS & NS \\
& & & & \\
VDS & 1992,1993 & S & S & NS \\
& 1993,1994 & S & S & NS \\
& 1994,1995 & S & S & NS \\
& 1995,1998 & NS & S & S \\
& 1998,2000 & S & S & NS \\
& 2000,2002 & S & NS & NS \\
\hline
\end{tabular}


populations. This phenomenon has also been observed in Canada (Reitsema et al. 2002). Two reasons for this can be suggested: (1) a delay of more than $10 \mathrm{yr}$ is needed to diminish TBT contamination significantly and allow imposex condition recovery of the populations, (2) measures other than legislation have led to a decrease in TBT pollution during the last decade.

\section{Delayed effect}

It is known that small boats coated with TBT-based antifouling paints in 1982 were not immediately recoated with reformulated paints and that furthermore, even after TBT prohibition, existing paint supplies were used illegally for years afterwards (Alzieu et al. 1989, Sarradin et al. 1991). Thus, a gradual de-

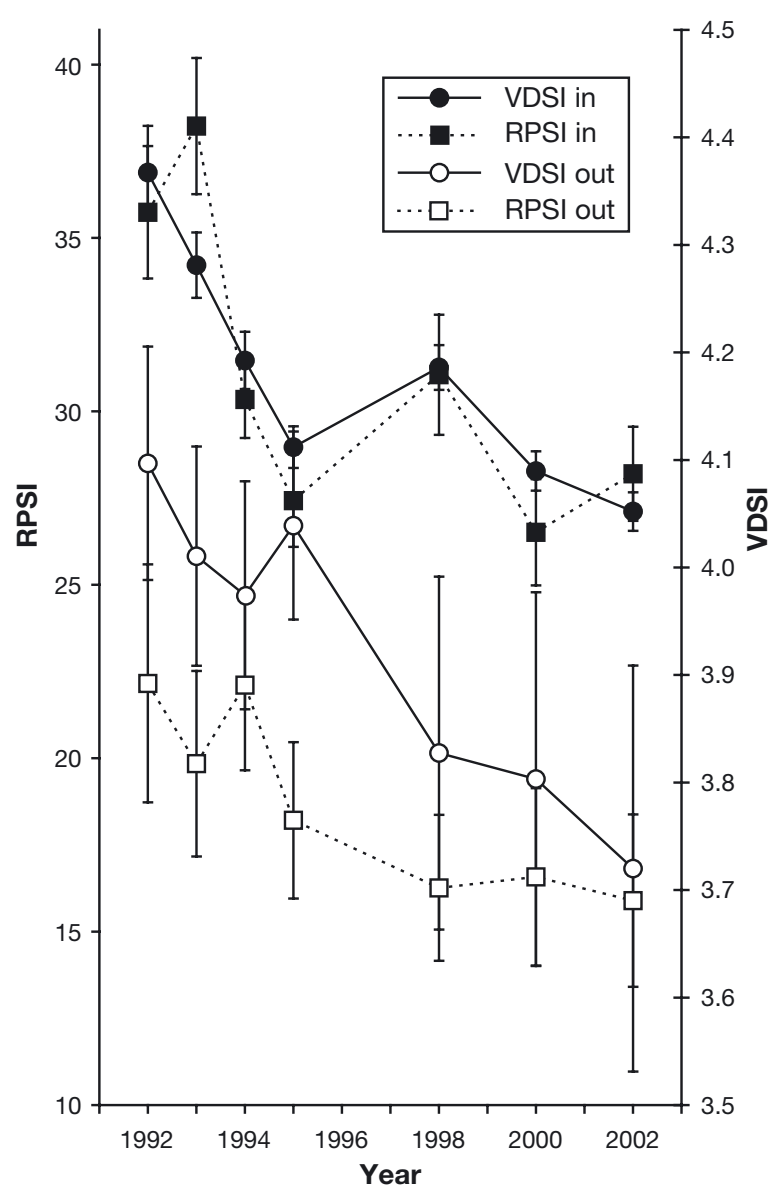

Fig. 3. Nucella lapillus. Temporal evolution of interpolated mean relative penis size (RPS) and vas deferens sequence (VDS) indices (means $\pm 1 \mathrm{SE}$ ) in NW Brittany. in: inside area of increasing imposex incidence in 1998 (Stns 8-31 and 38-51, see Fig. 2); out: outside area of increasing imposex condition (omitting Stns 28 and 29)

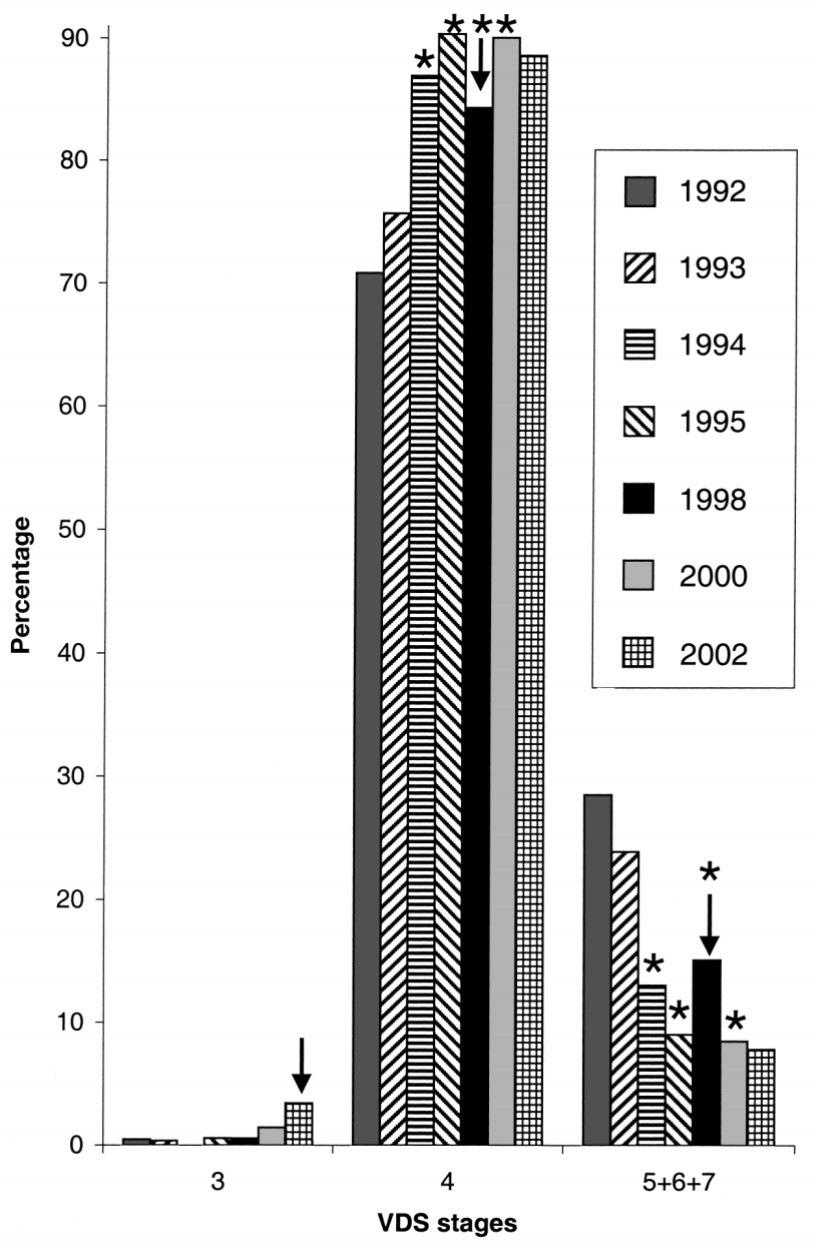

Fig. 4. Nucella lapillus. Temporal evolution of distribution of VDS stages at stations inside area of increasing imposex incidence in 1998 (see Fig. 2). *: significant difference from preceding survey $(\mathrm{p}<0.05)$

crease in TBT concentrations was expected. Concerning the biological response, imposex is irreversible (Féral 1980) and has been recorded for adults ranging in age from 2 to $>5$ yr (Feare 1970). Consequently, changes in imposex indices would also be delayed by at least 2 yr (after a meaningful reduction in water TBT concentrations had been achieved) before any observations of recovery would be made. Nevertheless, a decrease in imposex was still obvious in 2002, 20 yr after TBT restrictions were implemented.

Degradation of TBT in the water column occurs on the order of days or weeks, but degradation happens more slowly (on the order of years) in sediments, where TBT is strongly adsorbed and may be present in high concentrations (Stang \& Seligman 1987, Hwang et al. 1999). However, slow release of TBT from contaminated bottom sediments remains a potential longterm source of recontamination. 
Other possible causes

The main input of TBT into seawater is leaching from antifouling paints. Considering that the hull surface area coated with TBT-based antifouling paints has not diminished since 1992, a decrease in TBT input may be due to a slower leaching rate (Birchenough et al. 2002a,b). Manufacturers have improved their products and TBT leaching rates have been reduced significantly in new self-polishing copolymer paints. A further explanation for the decrease in seawater TBT contamination is a reduced input from shipyards: careening wastes have been progressively recycled and are no longer thrown directly into the sea.

\section{Increased imposex levels in 1998}

The geographical position of the stations involved in the imposex increase in 1998 confirms that an important source of TBT contamination originates in Brest Harbour. No exceptional amounts of dredging occurred during the study period. Thus, the increase in TBT contamination required to cause such a temporary change in the indices is probably not due to an exceptional desorption of TBT from sediments induced by dredging. The number of yachts has not increased markedly during the 1990s. No temporary increase in commercial ship traffic has occurred in the Bay of Brest over the last decade. The Chamber of Commerce of Brest (pers. comm.) indicates that the annual tonnage of discharged merchandise was $2.2 \times$ $10^{6}$, in 1994, $2.3 \times 10^{6}$, in 1998 and $2.4 \times 10^{6}$, in 2002 . Careening activities in Brest have been constant over the study period.

One event that may have caused an increase of TBT contamination in the study area was the launching of the nuclear aircraft carrier 'Charles de Gaulle' in October 1995. This vessel was coated with a TBTbased antifouling paint that had a TBT lixiviation rate of $0.17 \mu \mathrm{g} \mathrm{Sn} \mathrm{cm}^{-2} \mathrm{~d}^{-1}$, for a hull surface of $10360 \mathrm{~m}^{2}$ (Colin et al. 1995). Therefore, the lixiviation of TBT from the hull of the 'Charles de Gaulle' was about $16 \mathrm{~kg} \mathrm{yr}^{-1}$. This amount of TBT released into the Bay of Brest is high enough to explain an increase in imposex and its launching occurred in the right time frame. The aircraft carrier definitively left the Bay of Brest in the year 2000. As no assessment was done in 1996, 1997 or 1999, we do not know how high the maximum of our indices was or when it occurred. In order to attribute changes in imposex to specific events rather than addressing overall trends, imposex biomonitoring must be based on annual surveys.

\section{Imposex in NW Brittany}

Over the study period, environmental conditions within the Bay of Brest have somewhat improved with regard to TBT. The imposex survey of Nucella lapillus showed that the populations have suffered increasingly less female sterility and the populations have grown and colonised adjacent rocks at some sampling stations. The recovery of $N$. lapillus populations at Stns 29 and 39, where the species had disappeared, and the arrival of a new population between Stns 26 and 27 shows that the species is able to re-colonise areas where TBT pollution does not exceed the level that induces sterilisation of every female; a similar pattern was also reported from TBT-contaminated areas in Scotland (Birchenough et al. 2002b).

Despite the long-term improvement in the environmental conditions in Brest and the surrounding areas with respect to TBT contamination, the imposex condition of the Nucella lapillus populations remains severe inside the Bay of Brest. No population is free of imposex. Even if the percentages of sterility have decreased significantly during the last decade, sterility is still common within the Bay of Brest. In the extreme northeastern part of the bay, where N. lapillus was present in 1955 (Crisp \& Fischer-Piette 1959), only a few individuals were encountered in a restricted space at Stn 28. This is not a natural population. The individuals originate from commercial fishery activity that takes place there. Edible snails Littorina littorea are imported from Ireland and Great Britain, and the snails are placed in tanks filled with seawater before they are exported. Some N. lapillus may be present in the tanks, and a few individuals may have reached the shore when tanks were emptied into the sea. It is therefore not known how long the individuals we collected had been present. The presence of sexchanged females in this population proves that TBT contamination remains very high; high enough to impede the maintenance of a natural population. Those females that were still fertile had probably not spent enough time at this location to undergo sex-change (with spermiogenesis in the gonad) or sterilisation. Similar levels of TBT pollution (high enough to prevent the maintenance of $N$. lapillus populations) have been reported in Scotland (Harding et al. 1997), Ireland (Minchin et al. 1997), Spain (Ruiz et al. 1998), Norway (Følsvik et al. 1999), and Portugal (Barroso \& Moreira 2002).

The geographic distribution of the imposex indices is consistent with the results of studies using seawater and sediment TBT analyses, indicating that the main source of TBT contamination is in Brest Harbour (Michel \& Averty 1997, 1999, Chaumery \& Michel 2001). The contamination is spreading to the adjacent NW coasts, several dozen kilometres away, as sug- 
gested by the gradient of imposex indices from Stn 12 to Stn 4 (see Figs. 1 \& 2). Similar spatial imposex gradients were described by Bailey \& Davies (1988) in Shetland, Gibbs et al. (1987) in Cornwall, and Rilov et al. (2000) in Israel. Since the use of TBT in marine antifouling paints is supposed to be prohibited soon (see Champ 2000 for a review on regulatory strategies), it is hoped that environmental conditions in this area will improve further, that a re-colonisation by $N$. lapillus populations of the northern part of the Bay of Brest will occur, that female sterility will disappear in the vicinity of Brest, and that imposex-free populations will again appear in NW Brittany. It should be noted that imposex-free populations have only been observed in Iceland (Svavarsson \& Skarpheđinsdóttir 1995).

Acknowledgements. This work was partially funded by ASSEDICS de Bretagne, NSTF and RNO programs. Thanks to R. Marc and M. Briand for computing the maps. Special thanks to J. Guarini who read and commented on an early version of this manuscript. Contribution no. 906 of the IUEM, European Institute for Marine Studies (Brest, France).

\section{LITERATURE CITED}

Alzieu C, Héral M, Thibaud Y, Dardignac MJ, Feuillet M (1981) Influence des peintures antisalissures à base d'organostanniques sur la calcification de la coquille de l'huître Crassostrea gigas. Rev Trav Inst Pêches Marit 45:101-116

Alzieu C, Sanjuan J, Michel P, Borel M, Dreno JP (1989) Monitoring and assessment of butyltins in Atlantic coastal waters. Mar Pollut Bull 20:22-26

Bailey SK, Davies IM (1988) Tributyltin contamination around an oil terminal in Sullom Voe (Shetland). Environ Pollut 55:161-172

Bailey SK, Davies IM (1989) The effects of tributyltin on dogwhelks (Nucella lapillus) from Scottish coastal waters. J Mar Biol Assoc UK 69:335-354

Barroso CM, Moreira MH (2002) Spatial and temporal changes of TBT pollution along the Portuguese coast: inefficacy of the EEC directive 89/677. Mar Pollut Bull 44:480-486

Bech M (2002) A survey of imposex in muricids from 1996 to 2000 and identification of optimal indicators of tributyltin contamination along the east coast of Phuket Island, Thailand. Mar Pollut Bull 44:887-896

Bettin C, Oehlmann J, Stroben E (1996) TBT-induced imposex in marine neogastropods is mediated by an increasing androgen level. Helgol Meeresunters 50:299-317

Birchenough AC, Barnes N, Evans SM, Hinz H, Krönke I, Moss C (2002a) A review and assessment of tributyltin contamination in the North Sea, based on surveys of butyltin tissues burdens and imposex/intersex in four species of neogastropods. Mar Pollut Bull 44:534-543

Birchenough AC, Evans SM, Moss C, Welch R (2002b) Recolonisation and recovery of populations of dogwhelks Nucella lapillus (L.) on shores formerly subject to severe TBT contamination. Mar Pollut Bull 44:652-659

Bryan GW, Gibbs PE, Hummerstone LG, Burt GR (1986) The decline of the gastropod Nucella lapillus around southwest England: evidence for the effect of tributyltin from antifouling paints. J Mar Biol Assoc UK 66:611-640

Bryan GW, Burt GR, Gibbs PE, Pascoe PL (1993) Nassarius reticulatus (Nassariidae: Gastropoda) as an indicator of tributyltin pollution before and after TBT restrictions. J Mar Biol Assoc UK 73:913-929

Champ MA (2000) A review of organotin regulatory strategies, pending actions, related costs and benefits. Sci Total Environ 258:21-71

Chaumery CJ, Michel P (2001) Seasonal variations in degradation of tributyltin in the Brest naval harbour waters in relation to water temperature and insolation. Environ Technol 22:175-181

Colin R, Daniélou G, Mingant C, Duchêne J, Chaumery CJ, Guermeur E (1995) L'expérience pilote 'peintures antisalissures' de la Marine Nationale. Troisième Actes de Colloque Rencontres Scientifiques Internationales. Actes Colloq Int 2:110-137

Crisp DJ, Fischer-Piette E (1959) Répartition des principales espèces intercotidales de la côte atlantique française en 1954-1955. Ann Inst Océanogr 26:275-387

Evans SM, Hutton A, Kendall MA, Samosir AM (1991) Recovery in populations of the dogwhelks Nucella lapillus (L.) suffering from imposex. Mar Pollut Bull 22:331-333

Evans SM, Evans PM, Leksono T (1996) Widespread recovery of dogwhelks, Nucella lapillus (L.), from tributyltin contamination in the North Sea and Clyde Sea. Mar Pollut Bull 32:263-269

Feare CJ (1970) Aspects of the ecology of an exposed shore population of dogwhelks Nucella lapillus (L.). Oecologia 5:1-18

Féral C (1980) Influence de la qualité de l'eau de mer sur la différenciation d'un tractus génital mâle externe chez les femelles d'un mollusque gastéropode gonochorique: Ocenebra erinacea L. C R Hebd Séances Acad Sci Sér D 291: 775-778

Fioroni P, Oehlmann J, Stroben E (1991) The pseudohermaphroditism of prosobranchs; morphological aspects. Zool Anz 226:1-26

Følsvik N, Berge JA, Brevik EM, Walday M (1999) Quantification of organotin compounds and determination of imposex in populations of dogwhelks (Nucella lapillus) from Norway. Chemosphere 38:681-691

Fretter V, Graham A (1976) A functional anatomy of invertebrates. Academic Press, London

Gibbs PE (1993) A male genital defect in the dog-whelk, Nucella lapillus (Neogastropoda), favouring survival in a TBT-polluted area. J Mar Biol Assoc UK 68:715-731

Gibbs PE, Bryan GW, Pascoe PL, Burt GR (1987) The use of the dog-whelk, Nucella lapillus, as an indicator of tributyltin (TBT) contamination. J Mar Biol Assoc UK 67:507-523

Harding MJC, Rodger GK, Davies IM, Moore JJ (1997) Partial recovery of the dogwhelk (Nucella lapillus) in Sullom Voe Shetland from tributyltin contamination. Mar Environ Res 44:285-304

His E, Robert R (1980) Action d'un sel organo-métallique, l'acétate de tributyle-étain, sur les œufs et les larves D de Crassostrea gigas (Thunberg). Int Coun Explor Sea Comm Meet (Maricult Comm) 27:1-10

Huet M (1996) Estimation de la pollution par le tributylétain (TBT) en Bretagne occidentale à l'aide du bioindicateur imposex chez Nucella lapillus (L.) PhD thesis, Université de Bretagne Occidentale, Brest

Huet M, Paulet YM, Glémarec M (1996a) Tributyltin (TBT) pollution in the coastal waters of West Brittany as indicated by imposex in Nucella lapillus. Mar Environ Res 41:157-167

Huet M, Paulet YM, Le Pennec M (1996b) Survival of Nucella lapillus in a tributyltin-polluted area in west Brittany: a further example of a male genital defect (Dumpton syndrome) favouring survival. Mar Biol 125:543-549

Hwang HM, Oh JR, Kahng SH, Lee KW (1999) Tributyltin compounds in mussels, oysters and sediments of Chinhae 
Bay, Korea. Mar Environ Res 47:61-70

Michel P, Averty B (1997) Contamination des eaux de la rade de Brest par le tributyl étain (TBT). Ann Inst Océanogr 73: 25-34

Michel P, Averty B (1999) Contamination of French coastal waters by organotin compounds: 1997 update. Mar Pollut Bull 38:268-275

Minchin D, Oehlmann J, Duggan CB, Stroben E, Keatinge M (1995) Marine TBT antifouling contamination in Ireland, following legislation in 1987. Mar Pollut Bull 30:633-639

Minchin D, Bauer B, Oehlmann J, Schulte-Oehlmann U, Duggan CB (1997) Biological indicators used to map organotin contamination from a fishing port, Killybegs, Ireland. Mar Pollut Bull 34:235-243

Oehlmann J, Stroben E, Fioroni P (1991) The morphological expression of imposex in Nucella lapillus (Linnaeus) (Gastropoda: Muricidae). J Molluscan Stud 57:375-390

Oehlmann J, Stroben E, Fioroni P (1992) The rough tingle Ocenebra erinacea (Neogastropoda: Muricidae): an exhibitor of imposex in comparison to Nucella lapillus. Helgol Meeresunters 46:311-328

Ramon M, Amor MJ (2001) Increasing imposex in populations of Bolinus brandaris (Gastropoda: Muricidae) in the northwestern Mediterranean. Mar Environ Res 52:463-475

Rees CM, Brady BA, Fabris GJ (2001) Incidence of imposex in Thais orbita from Port Phillip Bay (Victoria, Australia), following 10 years of regulation on use of TBT. Mar Pollut Bull 42:873-878

Reitsema TJ, Thompson JAJ, Scholtens P, Spickett JT (2002) Further recovery of northeast Pacific neogastropods from

Editorial responsibility: Otto Kinne (Editor),

Oldendorf/Luhe, Germany imposex related to tributyltin contamination. Mar Pollut Bull 44:257-261

Rilov G, Gasith A, Evans SM, Benayahu Y (2000) Unregulated use of TBT-based antifouling paints in Israel (eastern Mediterranean): high contamination and imposex levels in two species of marine gastropods. Mar Ecol Prog Ser 192:229-238

Ruiz JM, Quintela M, Barreiro R (1998) Ubiquitous imposex and organotin bioaccumulation in gastropods Nucella lapillus from Galicia (NW Spain): a possible effect of nearshore shipping. Mar Ecol Prog Ser 164:237-244

Santos MM, Ten Hallers-Tjabbes CC, Santos AM, Vieira N (2002) Imposex in Nucella lapillus, a bioindicator for TBT contamination: re-survey along the Portuguese coast to monitor the effectiveness of EU regulation. J Sea Res 48: $217-223$

Sarradin PM, Astruc A, Desauziers V, Pinel R, Astruc M (1991) Butyltin pollution in surface sediments of Arcachon Bay after ten years of restricted use of TBT-based paints. Environ Technol 12:537-543

Stang PM, Seligman PF (1987) In situ adsorption and desorption of butyltin compounds from Pearl Harbor, Hawaii, sediment. In: Proceedings of the Organotin Symposium, Oceans '87 Conference, Halifax, Nova Scotia, Canada, 28 September-1 October, 1987, Vol 4. IEEE (Institute of Electrical and Electronics Engineers) New York, p 1386-1391

Svavarsson J, Skarpheđinsdóttir H (1995) Imposex in the dogwhelk Nucella lapillus (L.) in Icelandic waters. Sarsia 80: $35-40$

Submitted: April 23, 2003; Accepted: January 13, 2004

Proofs received from author(s): March 19, 2004 